\title{
The Enigmatic Amyntas and His Tomb
}

\author{
By Paavo Roos*
}

\begin{abstract}
Among the rock-cut tombs in Fethiye, the ancient Telmessus in western Lycia, there are three with temple façade fronts among numerous of other types. The most famous of them is the one called the Amyntas tomb after the short inscription cut on the left anta. The tomb has been mentioned by several travellers and scholars for centuries but never given a thorough description. Also, the inscription has been mentioned by several persons but has got much less interest than it deservesalthough it only consists of the name Amyntas and a patronymic there is a lot to discuss about it. In fact, the defective dealing with the inscription is as enigmatic as the existence of it and its connection with the tomb. Although many questions can easily be posed concerning the tomb the answers to give to them are difficult to find.
\end{abstract}

\section{Introduction}

Among the many rock-cut tombs in Fethiye (Telmessus) in western Lycia there are three chamber-tombs with temple façades overlooking the town and the harbour (Figure 1). The most famous is the first from the right (Figure 2) which is called the tomb of Amyntas after a short inscription on the left anta. ${ }^{1}$ Several mysteries are connected with the tomb however, not only with the tomb itself and its owner but also with the handling of it by the scholars and with each others' observations, as we shall see.

*Retired Lecturer, Lund University, Sweden.

1. Ilhan Akşit, Treasures of Turkey (Istanbul: Akşit culture and tourism publications, 1992), 103. 


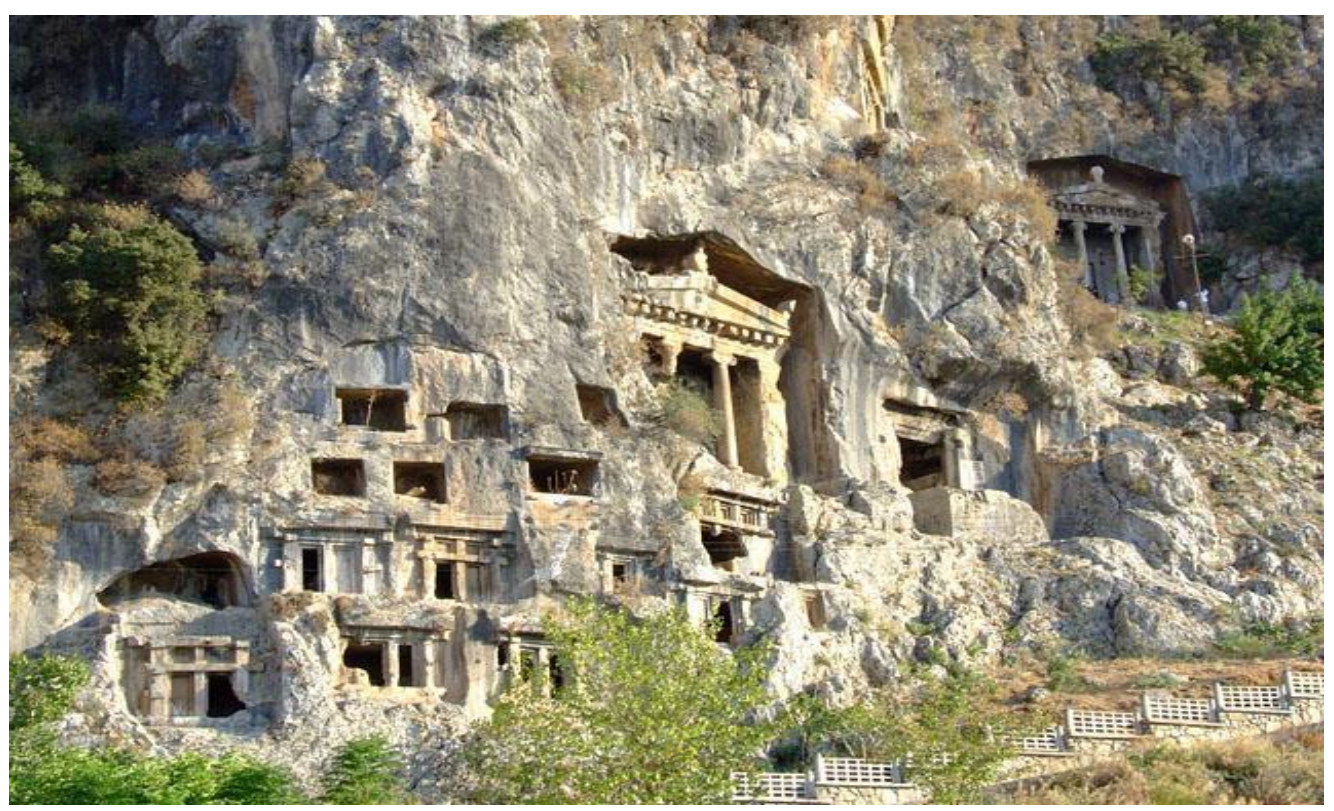

Figure 1. The three temple façade tombs among the Lycian tombs in Fethiye, tomb A right and tomb C left. Tomb B higher up between them is barely visible in this angle.

Source: Author.

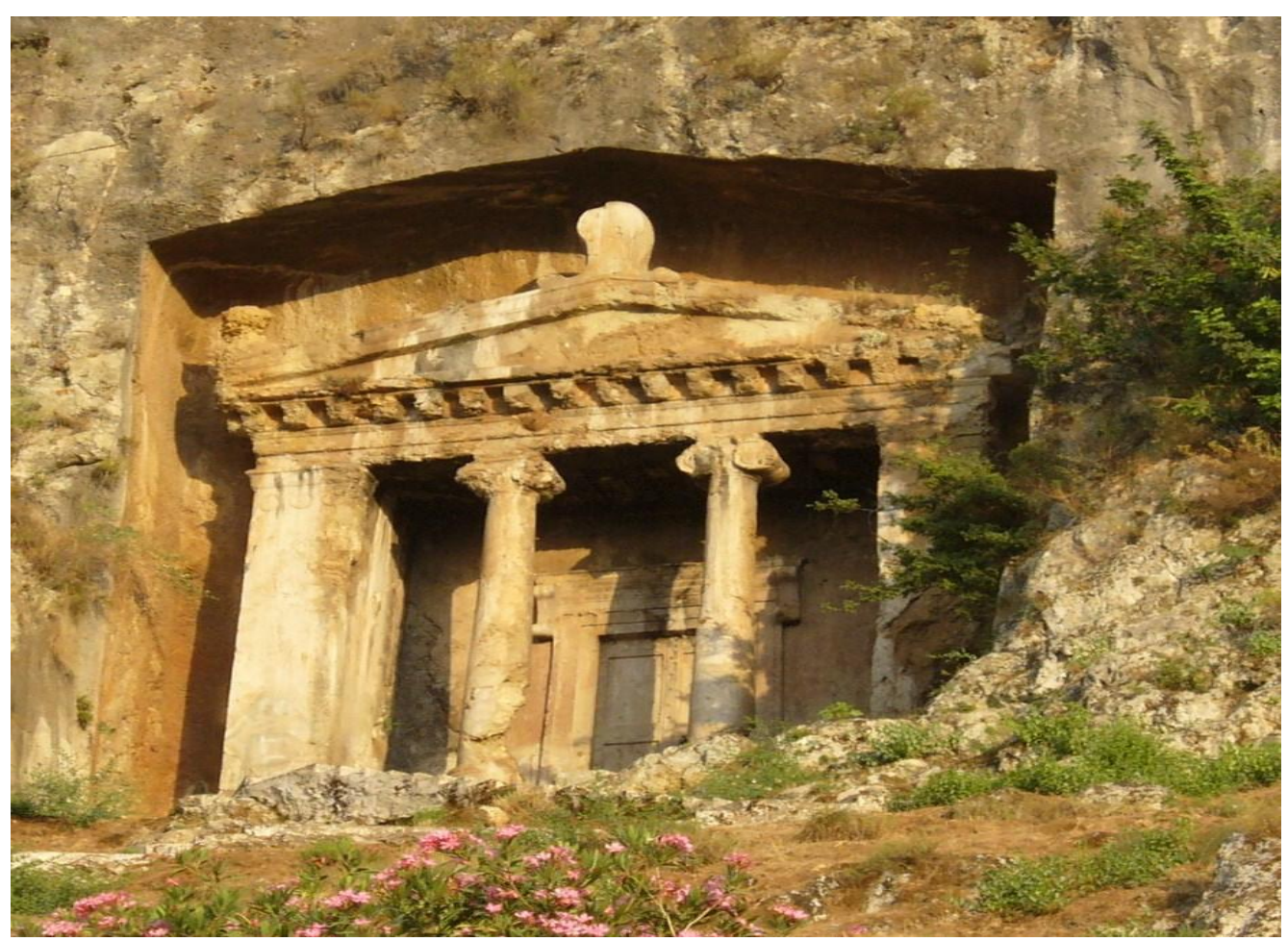

Figure 2. The Tomb of Amyntas

Source: Author. 


\section{Research History}

Fethiye has attracted many visitors during the centuries, as has the Amyntas tomb. The French traveller Charles Texier who visited the site in the 1840ies noticed like many later travellers that several of the predecessors had left their names cut in the rock and also on the tombs. Differently from other travellers he listed the signatures and made an account of them in his travel report ${ }^{2}$ and wrote that almost all of them were French and a couple of them were English and that the oldest were not from before 1780. The number of signatures has of course increased considerably after that, and a fact that Texier does not tell is that he himself has left his signature on the tomb, on the pronaos wall itself above the lintel. He must have had the aid of a ladder-the tomb is high and the site of his inscription is several metres above the pronaos floor. ${ }^{3}$

Of course, Texier has also studied and described the tomb itself. He mentions in short, the Ionic order with columns with volutes, the antae with the paterae, the entablement with the dentils and the acroteria and also the interior; he shows much interest in the door with panels and frame with knobs and also the consoles. ${ }^{4}$ Unfortunately everything that Texier has written cannot be trusted. The Austrian expedition that described and illustrated a large part of the western part of the south coast pointed out a couple of mistakes made by Texier and also gave the tomb a description and illustrations. ${ }^{5}$

But Texier is not the first person to show interest in the Amyntas tomb. Already in 1780, his fellowcountryman Choiseul-Gouffier spent much time on measuring and illustrating a tomb ${ }^{6}$ (and complained among other things of suffering caused by heat and mosquitos). He published an exact drawing of the façade with all measurements inserted, correctly as far as can be judged. This is,

2. Charles Texier and Richard Popplewell Pullan, Description de l'Asie Mineure III (Description of Asia Minor III) (Paris, 1849), 189.

3. Otto Benndorf and Georg Niemann, Reisen im südwestlichen Kleinasien 1, Reisen in Lykien und Karien (Travels in southwestern Asia Minor 1, travels in Lycia and Karia) (Wien: Carl Gerold's Sohn, 1884), 40; Lord Kinross, Europa Minor. Journeys in coastal Turkey (London: John Murray, 1956), 56.

4. Texier and Pullan, Description de l'Asie Mineure III; Texier, Asie Mineure. Description géographique, historique et archéologique des provinces et des villes de la chersonese d'Asie (Asia Minor. Geographical, historical and archaeological description of Provinces and cities of the Asian chersonese) (Paris, 1882), 668.

5. Benndorf and Niemann, Reisen im südwestlichen Kleinasien 1, 40.

6. Marie-Gabriel-Florent-Auguste de Choiseul-Gouffier, Voyage pittoresque dans l'empire ottoman, en Grèce, dans la Troade, les iles de l'archipel et sur les cotes de l'Asie Mineure (Picturesque trip in the Ottoman Empire, in Greece, in the Troad, the islands of the archipelago and on the coasts of Asia Minor) (Paris, 1782), 197, pl. 68. 
however, not the Amyntas tomb but the tomb further to the left, ${ }^{7}$ which displays a more normal height with the anta capitals located only slightly higher than the lintel (Figure 3). This tomb, which I will call tomb C is often illustrated but not commented, and no later author has reproduced Choiseul-Gouffier's drawing or even mentioned it. In $1801 \mathrm{Walsh}$ made an excursion from the peace negotiations after the Napoleonic war in Egypt and visited the town and made some illustrations, among them a not altogether correct drawing of a tomb. ${ }^{8}$ The dentil is wrong like the sides of the tympanon, the fascias of the architrave which usually are two in rock-tombs have become three like in normal architecture, and the antae look as if they are regarded as half-columns. That it is the Amyntas tomb that is meant and not tomb $C$ is shown by the height-the Amyntas tomb has several metres between the lintel and the pronaos ceiling, which is indeed remarkable. ${ }^{9}$

On the other hand, there is a well-executed and seemingly correct illustration of the Amyntas tomb in Fellows, ${ }^{10}$ where the height of the tomb is additionally accentuated by the small man placed in front of the door and not higher than the door opening.

During the $20^{\text {th }}$ century the Amyntas tomb has both been mentioned and illustrated several times but has never been given a thorough description, not even so much as has been given by the earlier travellers. In connection with the rebuilding of Fethiye after an earthquake in 1957 the tomb was furnished with a long cement staircase leading up to it and headlights for illuminating the façade; however, the lights have in fact seldom been turned on.

7. Benndorf and Niemann, Reisen im südwestlichen Kleinasien 1, 40 mention all three of them and refer to the difficulties of climbing the others but do not give any information concerning them: "Die mittlere ist unzugänglich, zu derjenigen linkerhand kann man zur Noth noch emporklimmen, in der Nähe betrachten lässt sich nur die dritte höchstgelegene, welche als Grab des Amyntas bekannt ist." The denomination Amyntas tomb could of course not appear before Texier published the inscription (see below). De Choiseul-Gouffier, Voyage pittoresque dans l'empire ottoman, does not mention the Amyntas tomb but it is visible to the right on his pl. 67, p. 193.

8. Thomas Walsh, Journal of the late campaign in Egypt. Including descriptions of that country, and on Gibraltar, Minorca, Malta, Marmorice, and Macri (London, 1803), pl. 16.

9. There is also the middle tomb which I will call tomb B, but it is unfinished and gives thus a few interesting details concerning the process of work.

10. Charles Fellows, A journal written during an excursion in Asia Minor (London, 1839), pl. 17, drawn by Scharf and also reproduced in Enid Slatter, Xanthus. Travels of discovery in Turkey (London: Rubicon Press, 1994), pl. 55. The journey of Fellows was in fact made after that of Texier, although it was published earlier. 


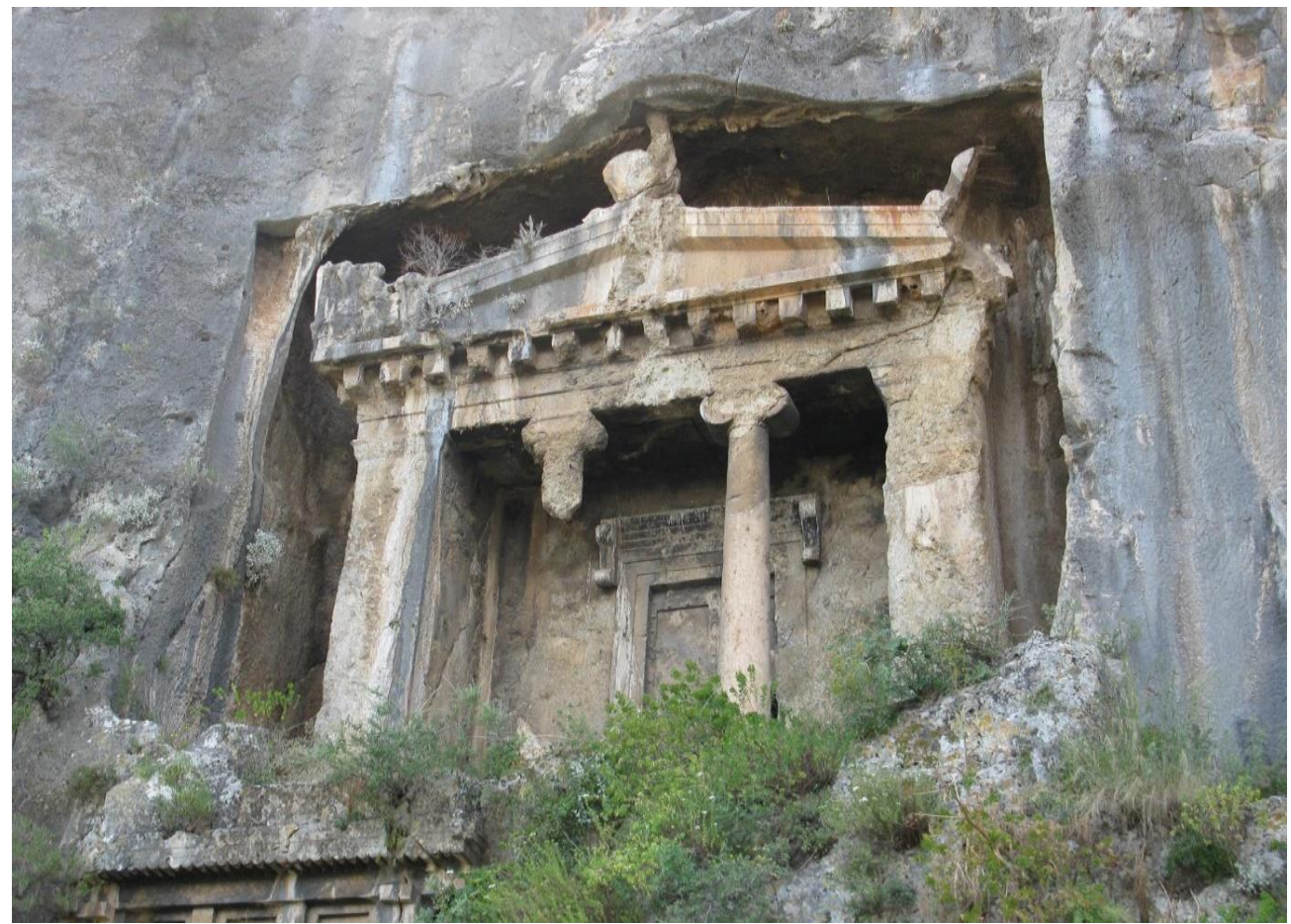

Figure 3. Tomb C

Source: Author

\section{Rock-Tombs in Anatolia}

Concerning rock-cut chamber-tombs in general they are very common in Anatolia-like in many other countries around the Mediterranean. They are far from being uniform but have a different execution in different provinces. Lycia has its characteristic woodwork-imitating façades whereas the neighbour province Caria in the south-west corner of the peninsula is hardly characterized by any original tomb façades. Sometime-evidently in the $4^{\text {th }}$ century BC-tomb façades executed like in Greek temples turn up in both Lycia and Caria but not in the whole provinces but in their frontier area, i.e., western Lycia and eastern Caria. ${ }^{11}$ Travellers of past centuries first encountered them in Lycia, and when they then saw them in Caria got the impression that the Carians copied them from the Lycians, whereas it for this type of rock-cut tombs as well could be the other way round. As copies of Lycian tombs, they were seen by Freya Stark, ${ }^{12}$ and we can still meet with formulations that the tombs in Caunus are Lycian (e.g., we can encounter touristic signboards saying "Visit the tombs of Lykia at Caunus").

11. Paavo Roos, "Rock-tombs in Hecatomnid Caria and Greek architecture," Architecture and Society in Hecatomnid Caria (Boreas, 17), (Uppsala, 1989), 64, fig. 1.

12. Freya Stark, The Lycian shore (London: John Murray, 1956), 111. 
A normal temple façade tomb from the Lyco-Carian border area has as a rule two columns in antis and a start of a corridor, sometimes in fact an entire corridor so that you can walk around the block. The columns are almost always Ionic with varying bases, with or without plinths. The capitals have volutes and sometimes a carved egg-and-dart, and under the anta capitals sometimes a line of rosettes or phialae is found. The epistyle has two fascias, not three as normal Greek architecture, and is crowned by a dentil with outsize teeth. The tympanon is seldom ornamented with reliefs. The roof is often crowned by acroteria that are sometimes decorated with reliefs-the central acroterion with a palmette and the lateral acroteria with a half-palmette or a sphinx. Sometimes the reliefs can be substituted by a painted decoration like in other parts of the tomb, but never relief and paint on the same detail. Behind the columns is a pronaos with a door leading to a chamber. It is often executed as an imitation of a double-door with lists, panels and sometimes knobs, all cut out from the rock and surrounded by an enframement crowned by a lintel flanked by consoles. The lintel has sometimes a painted or carved decoration in the form of an egg-and-dart or lotusand-palmette frieze. A part of the imitated door has an opening that has been closed with a door slab, in Lycia a sliding-door, in Caria a pivot-door. The opening leads to a rectangular chamber that has a bench around it on three sides. It may be quite smooth or have shallow or deep cuttings in the form of coffins. Sometimes the bench is provided with pillows cut out in the stone, and such may also exist in the coffins.

The Amyntas tomb has only shallow starts of a corridor. Among its characteristic treats is its conspicuous height. The Ionic column bases have the Attic variety and have plinths. The anta capitals have three rosettes, the only carved decoration on the tomb. The lintel has a painted decoration in three rows, something that the Austrian expedition criticizes Texier for having neglected. If any other painted decoration exists on capitals, acroteria or other parts with elevated location is not clear-anyhow it is not visible from below, and we have no information that anybody after Texier has climbed the tomb. Texier must have had a ladder for cutting or letting cut his name, but he reports nothing about more elevated details. Generally, it is often difficult to realize what Texier has in fact seen and what is hypothetical in his reconstructions. The imitated decoration of the door is magnificent; the righthand lower fourth part is open, and beyond the wall there is a groove for a sliding-door both in the floor and in the upper edge of the opening. The bench inside the chamber is provided with pillows, which makes it improbable that there have been coffins on it, as it has sometimes been suggested. ${ }^{13}$

13. Benndorf and Niemann, Reisen im südwestlichen Kleinasien 1, 41; Roos, The rocktombs of Caunus 1. The architecture (SIMA 34: 1) (Göteborg: Paul Åströms förlag, 1972), IV 155. 


\section{Whose Tomb?}

Whom a rock-tomb has been intended for is often not known. It is true that names are sometimes cut on or around tombs-in many cases certainly later additions-but the persons are usually unknown. Rock-tombs are seldom mentioned in ancient literature like the Mausoleum of Halicarnassus. Concerning the rock-tombs that are cut above Amasya in northern Anatolia they are mentioned by the geographer Strabo who was born in the city and told to be the monuments of the kings of Pontus. ${ }^{14}$ In Lycia inscriptions on tombs are much more common than in Caria which leads to the fact that the Lycian language is much more known than the Carian. But inscriptions do not only tell the name of the owner but can deal with other things like prohibition for non-authorized persons to reuse the tomb. Considering that there is often room for three persons in a chamber it is unsatisfactory that only one name occurs-is it the original burial that has been documented, and are the other burials in connection with that or are they much later? From literature we have many examples that the preparation of a tomb has started during the lifetime of the owner, above all when rulers are concerned, both in Egypt and in Persia, and of course also in Halicarnassus. ${ }^{15}$

In fact, the tomb of Amyntas has a very short inscription that in spite of its shortness should have caused many comments but that in reality seldom has led to more than references. It is a well-known fact that the inscription exists and that the tomb normally is called the tomb of Amyntas. The inscription is cut on the left anta and has the laconic formulation AMYNTOYTOYЕРМАПІОY, i.e. belonging to Amyntas with a patronymic. ${ }^{16}$ Texier has copied the inscription and executed it on his drawing of the tomb on his pl. 169, but it seems as if he has copied it on the spot and made the note "on the left anta" and then departed and executed the plate. The inscription that in reality is situated on the inner side of the anta (Figure 4) has been executed on the front in his plate and just below the rosettes

\section{Strabo XII 3.39.}

15. A good example is provided by Joseph from Arimatea in the NT. In Matth. 27.5760; Mark 15.43-46; Luke 23.50-53; John 19.38-42 the evangelists are rather unanimous in their reports. According to Matthew and John he was a disciple of Jesus and according to Mark and Luke he was one who looked forward to the kingdom of God. Concerning the tomb Mark says that the body of Jesus was laid in a tomb cut out of the rock and Luke also says that no one had been laid in it before, and John says that it was a new tomb, not yet used for burial. Matthew points out that it was Joseph who laid the body in his own unused tomb, which he had cut out of the rock. Joseph had thus provided a tomb for himself during his lifetime, but that is mentioned only by Matthew.

16. We shall return to the complicated question of the patronymic later. 
instead of two metres further down. ${ }^{17}$ Moreover the inscription has in his version become slightly mutilated since the article has been cut away; instead of AMYNTOYTOY in the first line AMYNTOY is given, in fact a fine example of a haplography.

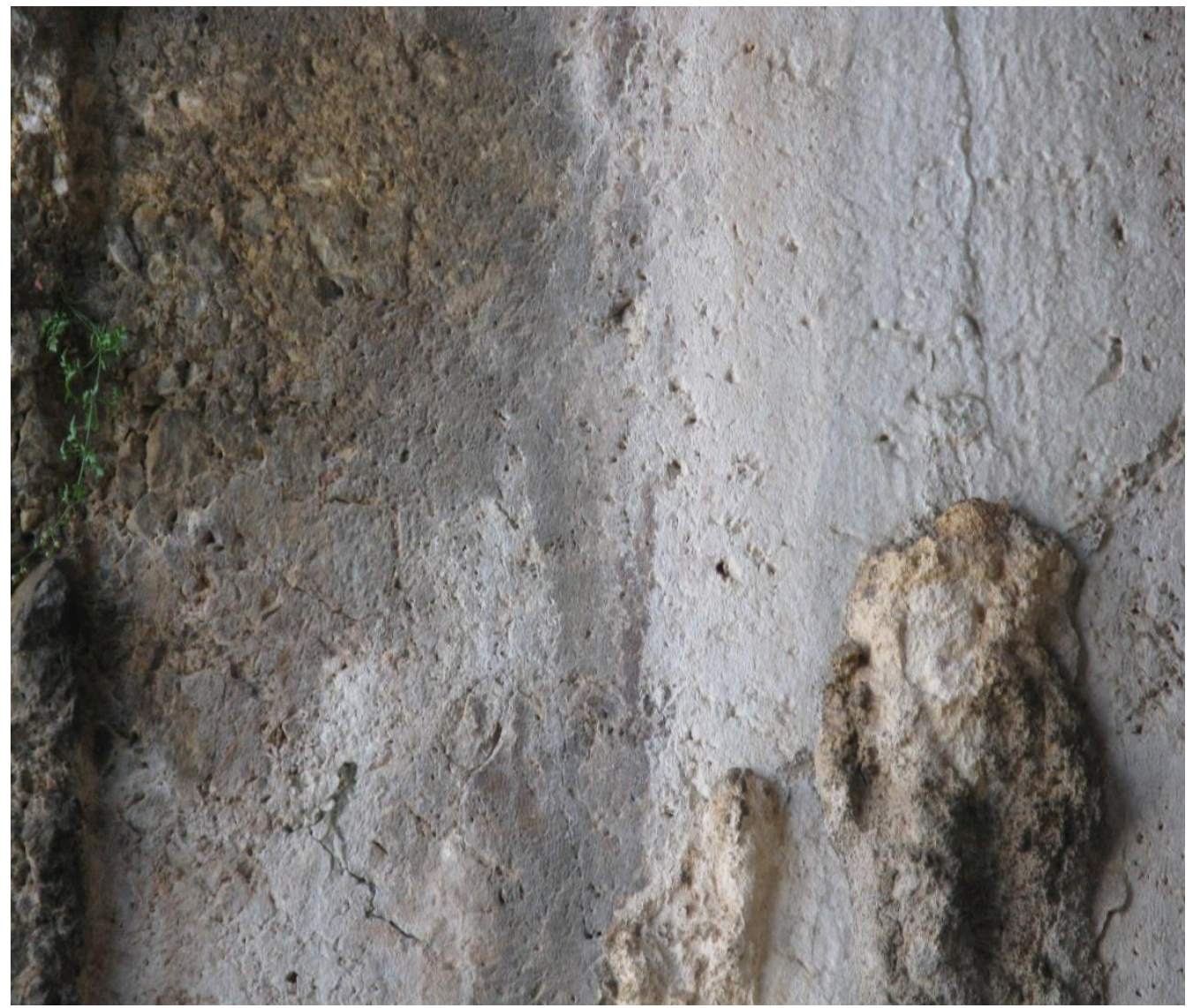

Figure 4. The tomb of Amyntas-Part of the inner side of the left anta-A few letters may be seen to the left

Source: Author.

But Texier is not the first one who has copied the inscription. J. von HammerPurgstall has among the inscriptions that he collected during his voyage in the Ottoman empire in 1811 rendered it and made the same mistake as Texier did later and missed a syllable and moreover read jota as rho and thus gave the name as Hermagrou. ${ }^{18}$ The omission of the article has the result that it is not shown that

17. See Benndorf and Niemann, Reisen im südwestlichen Kleinasien 1, 40. But the formulation "Sur l'ante à gauche on lit l'inscription..." followed by "La face des antes est ornée de trois patères" might indicate that Texier was conscious of the fact that the inscription was not on the front.

18. Johannes von Hammer, Topographische Ansichten, gesammelt auf einer Reise in die Levante (Topographic views collected on a trip to the Levant) (Wien, 1811), No. 28; for the form of the name see more below. 
it is a patronymic, and Hammer-Purgstall can interpret the name as Amyntas Hermagros. Texier could have made the same mistake, but since he does not render the name in the nominative it cannot be decided how he has interpreted it.

Before we enter the question of the identity of Amyntas some words about how the inscription has been dealt with after Texier may be appropriate. The Austrian expedition in the 1880ies includes in its criticism of Texier's description of the tomb a correction of the reading of the inscription and the location of it and gives a drawing of the inscription. ${ }^{19}$ This is later reproduced in the subsequent inscription publication. ${ }^{20}$ That the inscription is situated on the left anta is mentioned by most of those who deal with it at all, that it should be much further down than Texier's location is mentioned by few persons, ${ }^{21}$ and that location on the anta means the inner side of the anta and not on the front is not mentioned by anybody. In fact, the inscription should have been not only photographed but the exact measurements should have been given for the size of the letters, the width of the inscription and its exact location etc. Those who mention the inscription after the Austrian expedition give the reference to it in a way that they might have obtained by reading, and in fact nobody asserts having seen the inscription himself, still less devoted it a study.22 Now it is impossible to do it since the side of the anta is covered with calcareous deposits from water streaming down, and although it is a thin layer it is difficult to identify more than a few letters of the inscription (Figure 4). How long has it been like that? Were all letters quite legible in the 1880ies? Which is the last scholar that has been able to see the inscription in a good condition?

\section{The Problem of Amyntas}

Now who is Amyntas? In itself it is not an uncommon name; it occurs in the Macedonian royal dynasty in the Classical period and also among important

19. Benndorf and Niemann, Reisen im südwestlichen Kleinasien 1, 40, No. 9. The rendering of their fellow-countryman is not mentioned.

20. TAM II. Tituli Asiae Minoris collecti et editi auspiciis academiae litterarum Vindobonensis. II. Tituli Lyciae linguis graeca et Latina conscripti. 1. Pars Lyciae occidentalis cum Xantho oppido enarravit Ernestus Kalinka (Vindobonae, 1920) 12, no. 30.

21. George E. Bean, Lycian Turkey (London: Ernest Benn, 1978), 40; Bernhard Schmaltz, "Klassische Leitkultur und karische Provinz" (Classic leading culture and Carian province), Die Karer und die anderen, Kolloquium 2005 (Bonn: Habelt, 2009), 199 n. 188,202 n. 35.

22. I do not exclude myself. I saw the tomb for the first time in 1965 and made some notes concerning the superstructure with dentil and acroteria, columns, door with lintel and rosettes and interior but did not note anything about the inscription, the existence of which I of course knew; thus I cannot tell what it looked like then. 
persons in the army of Alexander the Great and the following generations and also later in Asia Minor. It occurs e.g. among the Galatian tetrarchs during the last century BC. Naturally it has been suggested that he was a Macedonian participant in Alexander's army who died in Telmessus which the army passed during its march, even though he is not mentioned in the literary sources. ${ }^{23}$ That would be a case with a parallel narrated by Xenophon about the commander Abradatas in the Persian army who was killed when Cyrus beleaguered Sardis and got a monumental tomb erected to him, a tomb that might be the so-called Pyramid tomb found above the river Pactolus. ${ }^{24}$

But how would that tally with the patronymic that is definitively not Macedonian? That is an intriguing case, and seemingly it is not even clear what the name is. As we have learnt a capital pi in Greek has two vertical stems and a horizontal one on top of them, but in fact the right vertical stem is often shorter and does not reach down to the bottom line. If it is short enough the letter may be mistaken for a gamma instead. It seems as there is no photo of the letter on the Amyntas tomb, but the drawing in Benndorf \& Niemann shows the right stem as exactly $50 \%$ of the left one. That would be enough for being interpreted as a pi, but since we have no exact information many scholars have regarded it as a gamma and thus given the genitive form as Hermagiou. ${ }^{25}$ If it is a $p i$ instead the genitive would be Hermapiou, but what is then the nominative? It could of course be Hermapios, and so it has been read by Texier and others have repeated it. ${ }^{26}$ But the nominative could also have been Hermapias, and so it has been read by Bean, followed by others. ${ }^{27}$ Henry observes that neither Hermagios nor Hermapias occurs in Lexicon of Greek personal names, nor does in fact Hermapios.

23. Among those who are mentioned in the sources we often know the patronymic, and moreover they usually lack a connection with Lycia.

24. Xenoph. Cyrop. VII 3.16; George M. A. Hanfmann, Letters from Sardis (Cambridge MA: Harvard University Press, 1972), 92, fig. 62; Christopher Ratté, "The 'Pyramid tomb' at Sardis," IstMitt 42 (1992): 160.

25. Sybille Haynes, Land of the Chimaera. An archaeological excursion in the South-West of Turkey (London: Chatto \& Windus, 1974), 54; Bernard Mc Donagh, Blue Guide, Turkey, the Aegean and Mediterranean coasts (London: A \& C Black Publishers, 1989), 401; Janos Fedak, Monumental tombs of the Hellenistic age (Toronto: University of Toronto Press, 1990), 142; Fedak, "Tombs and commemorative monuments," in Studies in Hellenistic architecture, ed. Frederick E. Winter (Toronto: University of Toronto Press, 2006), 86; Lucia Nováková, Tombs and burial customs in the Hellenistic Karia (Bonn: Rudolf Habelt, 2016), 64; and with an additional misreading (see above) Hammer, Topographische Ansichten, No. 28. See also Olivier Henry, Tombes de Carie (Bordeaux: Presses universitaires de Rennes, 2009), 161f, n. 60.

26. Texier and Pullan, Description de l'Asie Mineure III, 188; Texier, Asie Mineure, 668; Roos, The rock-tombs of Caunus 1, 110 n. 14; Roos, "Rock-tombs in Hecatomnid Caria," 65; Jane Laroche, Fethiye (Izmir: Türkiye turing ve otomobil kurumu, 1977), 15.

27. Bean, Lycian Turkey, 40; Cevdet Bayburtluoğlu, Lykia (Ankara: Ankara turismi, eskieserleri ve müzeleri sevenler derneği yayınları, n.d.), 70. 
The search should instead be made in Kleinasiatische Personennamen by Zgusta. Hermagios is not found there either but the genitive Hermapiou is, in a number of cases both in Lycia and further to the east, in Cilicia and Pamphylia. ${ }^{28}$ In the nominative only Hermapias occurs, only in a few cases just in Lycia. ${ }^{29}$ So it seems certain that the father's name was Hermapias.

Thus, the man in question had a Macedonian name whereas that of his father was a typical Anatolian name. If the separate names are interesting the combination is more so. Somebody in Alexander's army would hardly have a father with a typical indigenous Anatolian name, and if it is the question of a local dignitary who has given his son a Macedonian name that would in all probability mean a date after the conquest by Alexander. ${ }^{30}$ Could that fit? With that we have reached the question of the dating of the Amyntas tomb and other similar tombs.

\section{The Date of the Tomb}

Even if there have been suggestions of ascribing to the Amyntas tomb and other similar tombs a high age ${ }^{31}$ it has usually been agreed that the date should be the $4^{\text {th }}$ century BC, ${ }^{32}$ even though there has normally been nothing that supports it. The suggestions have been the middle or end of the century. ${ }^{33}$ An argument for the date has seldom been given, but Bean says that the inscription has letters of the fourth century $\mathrm{BC}^{34}$ and Akurgal gives the form of the painted ovolo as base

28. Ladislav Zgusta, Kleinasiatische Personennamen (Anatolian Person Names) (Prag: Československá akademie věd., 1964), 169f, § 355-20.

29. TAM II 1. The name is given as Hermapias already in Johannes Sundwall, Die einheimischen Namen der Lykier, nebst einem Verzeichnisse kleinasiatischer Namenstämme (The indigenous names of the Lycians, along with a list of Anatolian name stems) (Klio, Beih. 11), (Leipzig: Akademie-Verlag, 1913), 74.

30. We should perhaps not discard a suggested possibility that the man originally had an indigenous name and adapted a Macedonian one after Alexander's conquest.

31. Gottfried Semper, Der Stil in den technischen und tektonischen Künsten, oder praktische Aesthetik 1-2 (Style in technical and tectonic arts, or practical aesthetics 1-2) (München, 1863), 444, 450f.

32. It was already suggested by Fellows, Coins of ancient Lycia before the reign of Alexander (London, 1855), 1, 19, although he does not mention the Amyntas tomb especially, see Benndorf and Niemann, Reisen im südwestlichen Kleinasien 1, 41.

33. Texier, Asie Mineure, 668; Fedak, Monumental tombs of the Hellenistic age, 37; Fedak, "Tombs and commemorative monuments," 87; and Werner Tietz, Der Golf von Fethiye (The Gulf of Fethiye) (Bonn: Rudolf Habelt, 2003), 18 say the end of the 4th century.

34. Bean, Lycian Turkey, 40; Benndorf and Niemann, Reisen im südwestlichen Kleinasien 1, 41 and 113 say that the letters cannot be dated before 400 . 
for the dating to about 400 or the $4^{\text {th }}$ century. ${ }^{35}$ Scholars have seldom discussed the connection with corresponding tombs in Caria that also lacked a base for dating, ${ }^{36}$ and even for those simply the $4^{\text {th }}$ century was given. In no cases were there finds that could have given a dating for tombs in Caria, nor any inscriptions. Then came the excavations of the rock-cut tombs in Caunus in Caria in the 1960ies which gave rich finds of Attic pottery that could be dated to the middle of the $4^{\text {th }}$ century or just after it. ${ }^{37}$ That some of the tombs are unfinished has been connected to the arrival of Alexander the Great, i.e., the 330ies, ${ }^{38}$ which does not speak against that argument.

But for the Amyntas tomb and other similar tombs in Lycia there are no finds to provide a date, and if there is no cause to judge the Carian tombs as copied after the Lycian ones, can it be the other way round? ${ }^{39}$ Can the Amyntas tomb be younger than the tombs at Caunus? What similarities and differences are there in fact? Apart from the small differences that always exist between tombs of the same type and the difference that the Lycian chamber tombs have sliding doors and the Carian ones have pivot doors ${ }^{40}$ there is in fact only the tangible difference of the column bases. The larger tombs in Caunus have the Asiatic variety of the Ionic base ${ }^{41}$-unfortunately often unfinished-whereas the smaller tombs sometimes have a simplified variety. The Amyntas tomb has the Attic variety, which is perhaps not unexpected when we regard the existence of contacts between Lycia and Athens during the $4^{\text {th }}$ century. ${ }^{42} \mathrm{~A}$ chronological difference can hardly lie behind this detail. But it must be noticed that the combination of a plinth with an Attic base is an innovation of which the Amyntas tomb can be

35. About 400: Ekrem Akurgal, Die Kunst Anatoliens von Homer bis Alexander (The art of Anatolia from Homer to Alexander) (Berlin: W. de Gruyter, 1961), 129; 4th century: Akurgal, Ancient civilizations and ruins of Turkey (Istanbul: Mobil Oil Türk, 1970), 256. Albert Gabriel, En Turquie (Paris: Paul Hartmann, 1935), xiii says in the caption to pl. 124 not older than the 4th century in spite of some Archaic treats in profiles and volutes.

36 In Stark, The Lycian shore, and other similar references no date is given.

37. Roos, The rock-tombs of Caunus 2. The finds (SIMA 34: 2) (Göteborg: Paul Åströms förlag, 1974).

38. Paul Åström, "I de tusen törnrosastädernas land" (In the land of the Thousand sleeping beauties), Jorden Runt 29 (1957): 216; Roos, The rock-tombs of Caunus 1, 94.

39. Cf. the similar discussion concerning the Nereid monument in Xanthus and the Mausoleum in Halicarnassus, Poul Pedersen, "Architectural relations between Caria and Lycia at the time of the Ionian renaissance," Euploia. La Lycie et la Carie antiques. Dynamiques de territoires, échanges et identités (Euploia. Ancient Lycia and Caria. Dynamics of territories, exchanges and identities), Proceedings of the Bordeaux Conference, November 5, 6, and 7, 2009, ed. Patrice Brun, Laurence Cavalier, Koray Konuk, and Francis Prost (Bordeaux: Ausonius, 2013), 132-139.

40. Roos, "The rock-tomb doors of the Lyco-Carian borderland," Opuscula Atheniensia 10 (1970): 25-30.

41. Roos, The rock-tombs of Caunus 1; Roos, "Rock-tombs in Hecatomnid Caria, 66.

42. Benndorf and Niemann, Reisen im südwestlichen Kleinasien 1, 40, Fig. 28, 113. 
regarded as the first example, whatever its date may be. ${ }^{43}$ In Caria plinths often occur in smaller rock-tombs, and then combined with column bases with a simplified order.

\section{The Location of the Inscription}

To return to the inscription and its connection with the tomb it is in fact not self-evident that they belong together and shall be given the same date, even if most scholars presuppose so when they mention alternative possibilities. It is a common feature with rock-cut tombs that they are not only reused but also provided with new inscriptions, whether there are original ones or not. In fact a coupling between the tomb and the inscription is only made by Benndorf and Niemann ${ }^{44}$ who say that nothing says that the inscription is a later addition, and Bean uses just the inscription as foundation for a date. ${ }^{45}$ Thus it is a little surprising to be confronted with the opinion of Schmaltz that the inscription cannot be used for dating the tomb since it is probably a later addition. ${ }^{46}$ His only argument is the location of the inscription in half-height on the anta. It is true that it is easier for a re-user of a tomb to cut an inscription in half-height on the inner side of an anta than in the place where Texier draws it. ${ }^{47}$ But does that make a proof that the inscription is secondary? And where would the inscription be located if it were original? Schmaltz suggests above the door like the Carian

43. Frederick E. Winter, Studies in Hellenistic architecture (Toronto: University of Toronto Press, 2006), 8, 276, n. 24; Roos, "Rock-tombs in Hecatomnid Caria," 66.

44. Benndorf and Niemann, Reisen im südwestlichen Kleinasien 1, 41 "...ist die Inschrift nicht etwa eine spätere Zuthat, wofür indessen nichts Triftiges sich anführen lässt..." ("...if the inscription is not a later addition, for which, however, nothing conclusive can be stated").

45. Bean, Lycian Turkey, 40 "in letters of the fourth century BC."

46. Schmaltz, "Klassische Leitkultur und karische Provinz," 199 n. 18, "...gibt die Inschrift kaum einen verbindlichen Hinweis, da sie wohl nachträglich an der Ante angebracht worden ist (die Anbringung der Inschrift in halber Höhe der Ante könnte auf sekundäre Nutzung des Grabes deuten)" ["the inscription gives hardly a conclusive indication as it is no doubt applied later on the anta) (the application of the inscription in half-height on the anta could indicate a secondary use of the tomb)]"; 202 n. 35, "...eine griechische Inschrift, wohl nachträglich zugefügt, in halber Höhe auf der linken Ante" ("...a Greek inscription, no doubt added later, in half-height on the left anta)."

47. Cf. the temple of Athena in Priene, Martin Schede, Die Ruinen von Priene (The Ruins of Priene) (Berlin: Walter de Gruyter, 1964), 30, Abb. 41; Gottfried Gruben, Die Tempel der Griechen (The Temples of the Greeks), 2nd ed. (München: Hirmer Verlag, 1976), 385. 
inscription on tomb E1 in Caunus or the tomb in Mezargediği west of Caunus, but they are hardly comparable with tombs with columns in antis. ${ }^{48}$

Where would the inscription have been located on a temple-tomb if it had been original? We are used to inscriptions on the architrave, but we shall observe that it hardly occurred on tombs from the $4^{\text {th }}$ century. That the Hecatomnid buildings in Labraunda from the middle of the $4^{\text {th }}$ century have inscriptions on the architrave $^{49}$ is an innovation, and the only rock-tomb in Caria with an inscription on the architrave is certainly from a later date to judge from the architecture. ${ }^{50}$

But the door-panel is also a common place for the location of inscriptions on rock-tombs, and already Choiseul-Gouffier noticed the existence of an inscription on the tomb that he had reproduced but mentioned also that he found it impossible to decipher in spite of the efforts to wash it (Figure 5). ${ }^{51}$ However, a number of later travellers have thought themselves able to read it, even though there are small discrepancies between their readings. ${ }^{52}$ Here we even get the measurements for the inscription that are missing for the Amyntas inscription.

It is a very interesting fact that this tomb, apart from the inscription on the door-panel also has an inscription on the inner side of the anta, in this case the right one. It is not mentioned by Choiseul-Gouffier but is rendered by the same

48. Roos, The rock-tombs of Caunus 1, 1972, 42, 93, pls. 15, 40; for Mezargediği which is a built tomb see Baki Öğün, Cengiz Işık, Adnan Diler, Oguz Özer, Bernhard Schmaltz, Christian Marek, and Münife Doyran, Kaunos Kbid [The results of 35 years of research (19662001)] (Izmir: Mopak cultural heritage, 2002), 174, fig. 126.

49. See Pontus Hellström, Labraunda. A guide to the Karian sanctuary of Zeus Labraundos (Istanbul: Eğe Yayınları, 2007), 86-128.

50. Tomb 1 in Taşyenice, Roos, Survey of rock-cut chamber-tombs in Caria 2. Central Caria (SIMA 72: 2) (Göteborg: Paul Åströms förlag, 2006), 36f, pl. 46. Already Benndorf and Niemann, Reisen im südwestlichen Kleinasien 1, 41 notice that inscriptions on the architrave do not appear until in Hellenistic time.

51. De Choiseul-Gouffier, Voyage pittoresque dans l'empire ottoman, 122 "...si effacée, que malgré toute la peine que nous prîmes pour la laver il nous fut impossible de le dechiffrer ("...so worn that in spite of all the pain we had with washing it, it was impossible for us to decipher it").

52. See TAM II:1, 17 nos. 46-47. TAM describes the tomb "sepulcrum e rupe excisum cum porticu" and does not mention Choiseul-Gouffier here since he does not report the inscription, and it is not clear which the tomb in question is; that a picture of tomb B in the same group is placed on the page may give the impression that it is the question of that tomb. However, tomb B is unfinished and lacks inscriptions. Instead the tomb illustrated in William Bell Dinsmoor, The architecture of ancient Greece, 3rd ed. (London: B.T. Batsford, 1950), Pl. XIX with an inscription on the door-panel seems to be tomb C. From where Dinsmoor has taken this old picture is not evident-just this illustration lacks the source that is given for the rest of the figures in the introduction. Anyhow, it is not from Choiseul-Gouffier although the outline is very similar-the execution is different. 
other travellers and is shown on the same page in TAM. ${ }^{53}$ The rendering shows a facsimile and indicates that both inscriptions have the same execution and thus can be regarded as contemporary.

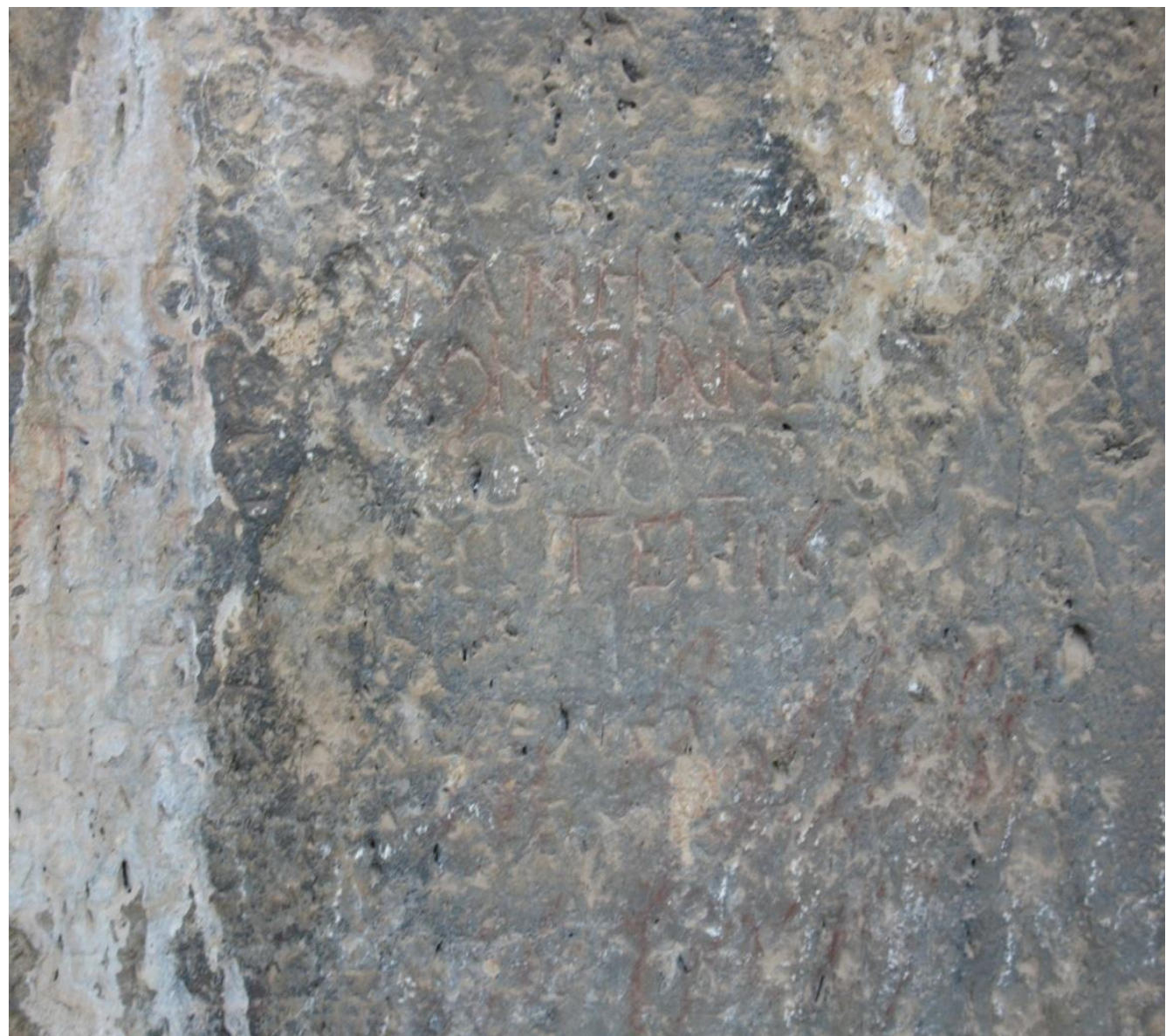

Figure 5. Tomb C. Inscription on Left Door Panel

Source: Author

\section{Conclusion}

It is not easy to give a conclusion with answers to the questions that can be posed concerning the tomb and its owner. So much is clear that the person has a Macedonian name and his father an indigenous one, which would indicate with probability but not for quite certain that he was born after Alexander's conquest. That would in its turn mean that either the tomb is from the end of the $4^{\text {th }}$ century $\mathrm{BC}$ or even later-or that the inscription is a later addition, If the latter is the case, the location on the anta would support the hypothesis, but I would not use it as a

53. TAM II, loc.cit., no. 47. 
proof for it, especially as there is no "natural" location for an original inscription on a temple-tomb in that period or area. Also, other possible explanations may be considered, like the one that the person had another name originally and for some reason changed it later. Whereas still other questions can be posed, on the other hand few answers or explanations can be given, Amyntas, son of Hermapias still remains the enigmatic individual and his tomb subject to questions.

\section{Bibliography}

Akşit, Ilhan. Treasures of Turkey. Istanbul: Akşit culture and tourism publications, 1992.

Akurgal, Ekrem. Die Kunst Anatoliens von Homer bis Alexander (The art of Anatolia from Homer to Alexander). Berlin: W. de Gruyter, 1961.

Akurgal, Ekrem. Ancient civilizations and ruins of Turkey. Istanbul: Mobil Oil Türk, 1970.

Åström, Paul. "I de tusen törnrosastädernas land" (In the land of the Thousand sleeping beauties). Jorden Runt 29 (1957): 201-216.

Bayburtluoğlu, Cevdet. Lykia. Ankara: Ankara turismi, eskieserleri ve müzeleri sevenler derneği yayınları, n.d.

Bean, George E. Lycian Turkey. London: Ernest Benn, 1978.

Benndorf, Otto, and Georg Niemann. Reisen im südwestlichen Kleinasien 1, Reisen in Lykien und Karien (Travels in southwestern Asia Minor 1, travels in Lycia and Karia). Wien: Carl Gerold's Sohn, 1884.

de Choiseul-Gouffier, Marie-Gabriel-Florent-Auguste. Voyage pittoresque dans l'empire ottoman, en Grèce, dans la Troade, les iles de l'archipel et sur les cotes de l'Asie Mineure (Picturesque trip in the Ottoman Empire, in Greece, in the Troad, the islands of the archipelago and on the coasts of Asia Minor). Paris, 1782.

Dinsmoor, William Bell. The architecture of ancient Greece, $3^{\text {rd }}$ ed. London: B.T. Batsford, 1950.

Fedak, Janos. Monumental tombs of the Hellenistic age. Toronto: University of Toronto Press, 1990.

Fedak, Janos. "Tombs and commemorative monuments." In Studies in Hellenistic architecture, edited by Frederick E. Winter. Toronto: University of Toronto Press, 2006.

Fellows, Charles. A journal written during an excursion in Asia Minor. London, 1839.

Fellows, Charles. Coins of ancient Lycia before the reign of Alexander. London, 1855.

Gabriel, Albert. En Turquie. Paris: Paul Hartmann, 1935.

Gruben, Gottfried. Die Tempel der Griechen (The Temples of the Greeks), $2^{\text {nd }}$ ed. München: Hirmer Verlag, 1976.

Hanfmann, George M. A. Letters from Sardis. Cambridge MA: Harvard University Press, 1972. 
Haynes, Sybille. Land of the Chimaera. An archaeological excursion in the South-West of Turkey. London: Chatto \& Windus, 1974.

Hellström, Pontus. Labraunda. A guide to the Karian sanctuary of Zeus Labraundos. Istanbul: Ĕge Yayınları, 2007.

Henry, Olivier. Tombes de Carie. Bordeaux: Presses universitaires de Rennes, 2009.

Kinross, Lord. Europa Minor. Journeys in coastal Turkey. London: John Murray, 1956.

Laroche, Jane. Fethiye. Izmir: Türkiye turing ve otomobil kurumu, 1977.

Mc Donagh, Bernard. Blue Guide, Turkey, the Aegean and Mediterranean coasts. London: A \& C Black Publishers, 1989.

Nováková, Lucia. Tombs and burial customs in the Hellenistic Karia. Bonn: Rudolf Habelt, 2016.

Öğün, Baki, Cengiz Işık, Adnan Diler, Oguz Özer, Bernhard Schmaltz, Christian Marek, and Münife Doyran. Kaunos Kbid [The results of 35 years of research (19662001)]. Izmir: Mopak cultural heritage, 2002.

Pedersen, Poul. "Architectural relations between Caria and Lycia at the time of the Ionian renaissance." In Euploia. La Lycie et la Carie antiques. Dynamiques de territoires, échanges et identités (Euploia. Ancient Lycia and Caria. Dynamics of territories, exchanges and identities). Proceedings of the Bordeaux conference, November 5, 6 and 7, 2009, edited by Patrice Brun, Laurence Cavalier, Koray Konuk, and Francis Prost. Bordeaux: Ausonius, 2013.

Ratté, Christopher. "The 'Pyramid tomb' at Sardis." IstMitt 42 (1992): 135-161.

Roos, Survey of rock-cut chamber-tombs in Caria 2. Central Caria (SIMA 72: 2). Göteborg: Paul Åströms förlag, 2006.

Roos, Paavo. "Rock-tombs in Hecatomnid Caria and Greek architecture." Architecture and society in Hecatomnid Caria (Boreas, 17). Uppsala, 1989.

Roos, Paavo. The rock-tombs of Caunus 1. The architecture (SIMA 34: 1). Göteborg: Paul Åströms förlag, 1972.

Roos, Paavo. The rock-tombs of Caunus 2. The finds (SIMA 34: 2). Göteborg: Paul Åströms förlag, 1974.

Roos, Paavo. "The rock-tomb doors of the Lyco-Carian borderland." Opuscula Atheniensia 10 (1970): 25-30.

Schede, Martin. Die Ruinen von Priene (The Ruins of Priene). Berlin: Walter de Gruyter, 1964.

Schmaltz, Bernhard. "Klassische Leitkultur und karische Provinz" (Classic leading culture and Carian province). Die Karer und die anderen, Kolloquium 2005. Bonn: Habelt, 2009.

Semper, Gottfried. Der Stil in den technischen und tektonischen Künsten, oder praktische Aesthetik 1-2 (Style in technical and tectonic arts, or practical aesthetics 12). München, 1863.

Slatter, Enid. Xanthus. Travels of discovery in Turkey. London: Rubicon Press, 1994.

Stark, Freya. The Lycian shore. London: John Murray, 1956. 
Sundwall, Johannes. Die einheimischen Namen der Lykier, nebst einem Verzeichnisse kleinasiatischer Namenstämme (The indigenous names of the Lycians, along with a list of Anatolian name stems) (Klio, Beih 11). Leipzig: Akademie-Verlag, 1913.

TAM II. Tituli Asiae Minoris collecti et editi auspiciis academiae litterarum Vindobonensis. II. Tituli Lyciae linguis graeca et Latina conscripti. 1. Pars Lyciae occidentalis cum Xantho oppido enarravit Ernestus Kalinka. Vindobonae, 1920.

Texier, Charles. Asie Mineure. Description géographique, historique et archéologique des provinces et des villes de la chersonese d'Asie (Asia Minor. Geographical, historical and archaeological description of Provinces and cities of the Asian chersonese). Paris, 1882.

Texier, Charles, and Richard Popplewell Pullan. Description de l'Asie Mineure III (Description of Minor Asia III). Paris, 1849.

Tietz, Werner. Der Golf von Fethiye (The Gulf of Fethiye). Bonn: Rudolf Habelt, 2003.

von Hammer, Johannes. Topographische Ansichten, gesammelt auf einer Reise in die Levante (Topographic views collected on a trip to the Levant). Wien, 1811.

Walsh, Thomas. Journal of the late campaign in Egypt. Including descriptions of that country, and on Gibraltar, Minorca, Malta, Marmorice, and Macri. London, 1803.

Winter, Frederick E. Studies in Hellenistic architecture. Toronto: University of Toronto Press, 2006.

Zgusta, Ladislav. Kleinasiatische Personennamen (Anatolian Person Names). Prag: Československá akademie vĕd., 1964. 